\title{
Winter Ecology and Spring Dispersal of Common Ravens in Wyoming
}

\author{
Author(s): Luke W. Peebles and Michael R. Conover
}

Source: Western North American Naturalist, 77(3):293-308.

Published By: Monte L. Bean Life Science Museum, Brigham Young University https://doi.org/10.3398/064.077.0303

URL: http://www.bioone.org/doi/full/10.3398/064.077.0303

BioOne (www.bioone.org) is a nonprofit, online aggregation of core research in the biological, ecological, and environmental sciences. BioOne provides a sustainable online platform for over 170 journals and books published by nonprofit societies, associations, museums, institutions, and presses.

Your use of this PDF, the BioOne Web site, and all posted and associated content indicates your acceptance of BioOne's Terms of Use, available at www.bioone.org/page/ terms of use.

Usage of BioOne content is strictly limited to personal, educational, and non-commercial use. Commercial inquiries or rights and permissions requests should be directed to the individual publisher as copyright holder. 


\title{
WINTER ECOLOGY AND SPRING DISPERSAL OF COMMON RAVENS IN WYOMING
}

\author{
Luke W. Peebles ${ }^{1}$ and Michael R. Conover ${ }^{1,2}$
}

\begin{abstract}
Numbers of Common Ravens (Corvus corax) have increased in western North America, and these high abundances are the source of problems throughout the species' range. Little is known about the winter ecology of ravens. We studied a population of ravens in Wyoming during the winters of 2013-2015; our goals were to examine use of landfills for foraging and use of anthropogenic structures for roosting, as well as dispersal patterns of ravens from these landfills in the spring. On average, $22 \%$ of radio-marked ravens foraged at landfills on a given day and $68 \%$ roosted at anthropogenic sites (e.g. on buildings or underneath bridges) each night. Daily counts at an anthropogenic roost and at the nearest landfill were positively correlated. Decreased temperatures increased raven use of landfills and anthropogenic roost sites. In the spring, radio-marked and GPS-marked ravens $(n=56)$ dispersed an average of $38 \mathrm{~km}$ from the landfills where they were captured. Use of landfills and anthropogenic roost sites in the winter likely contributes to an increase in the number of ravens by improving survival and body condition of breeding-age birds. In the spring, ravens moved outward from these locations, and the area most susceptible to raven damage was localized within a 40-km radius of where ravens wintered.
\end{abstract}

Resumen.-El número de cuervos (Corvus corax) al oeste de América del Norte aumentó, lo que ha sido un factor problemático a lo largo de su hábitat. Además, se conoce poco acerca de su ecología durante el invierno. Estudiamos una población de cuervos en Wyoming durante los inviernos de 2013-2015. Nuestros objetivos fueron examinar el uso de los vertederos durante el forrajeo y el uso de las estructuras antropogénicas durante el reposo, así como los patrones de dispersión de los cuervos en estos vertederos, durante la primavera. En promedio, el $22 \%$ de los cuervos radio-marcados se alimentaron en los vertederos en un día determinado y el 68\% descansó en sitios antropogénicos cada noche (por ejemplo, edificios o debajo de puentes). Los conteos diarios entre un sitio de descanso antropogénico y el vertedero más cercano se correlacionaron positivamente. La disminución en las temperaturas provocó que los cuervos utilizaran más los vertederos y sitios antropogénicos. En la primavera, los cuervos radio-marcados y aquellos marcados con GPS $(n=56)$ se alejaron, en promedio, unos $38 \mathrm{~km}$ de los vertederos donde fueron capturados. En el invierno, el uso de los vertederos y de los sitios de descanso antropogénicos contribuye, posiblemente, al aumento del número de cuervos, ya que mejora su supervivencia y la condición corporal de las aves en edad reproductiva. En la primavera, los cuervos se alejaron de estos sitios, y el área más susceptible de daño por los cuervos se identificó dentro de un radio de 40 kilómetros de donde hibernaron.

Common Raven (Corvus corax; hereafter raven) numbers have increased severalfold in the western United States during the last several decades (Boarman 1993, Boarman and Berry 1995, Sauer et al. 2011). These ravens pose health and safety hazards to humans by roosting and defecating in areas used by humans (Engel et al. 1993, Merrell 2012). Ravens also kill young livestock (Larson and Dietrich 1970, Spencer 2002) and wildlife species including the desert tortoise (Gopherus agassizii), California Least Tern (Sterna antillarum browni), and Greater Sage-Grouse (Centrocercus urophasianus; Linz et al. 1990, Boarman 2003, Coates et al. 2008). Studies on raven ecology usually occur during the spring and summer when ravens cause problems. By comparison, little research has focused on the winter ecology of ravens in the western U.S. What is known about the winter ecology of ravens in the western U.S. suggests that it is different from that of ravens in the eastern U.S. Ravens in the western U.S. utilize landfills heavily in winter (Dorn 1972, Preston 2005), whereas exposed carcasses are the main winter food source of ravens in the eastern U.S. (Heinrich 1988, Marzluff and Heinrich 1991, Wright et al. 2003). In the West, ravens often roost in anthropogenic structures rather than in trees and on natural substrate as they do in the East (Brown 1974, Lucid and Conner 1974, Temple 1974, Engel et al. 1992, Cotterman and Heinrich 1993, Marzluff et al. 1996, Wright et al. 2003, Merrell 2012). 


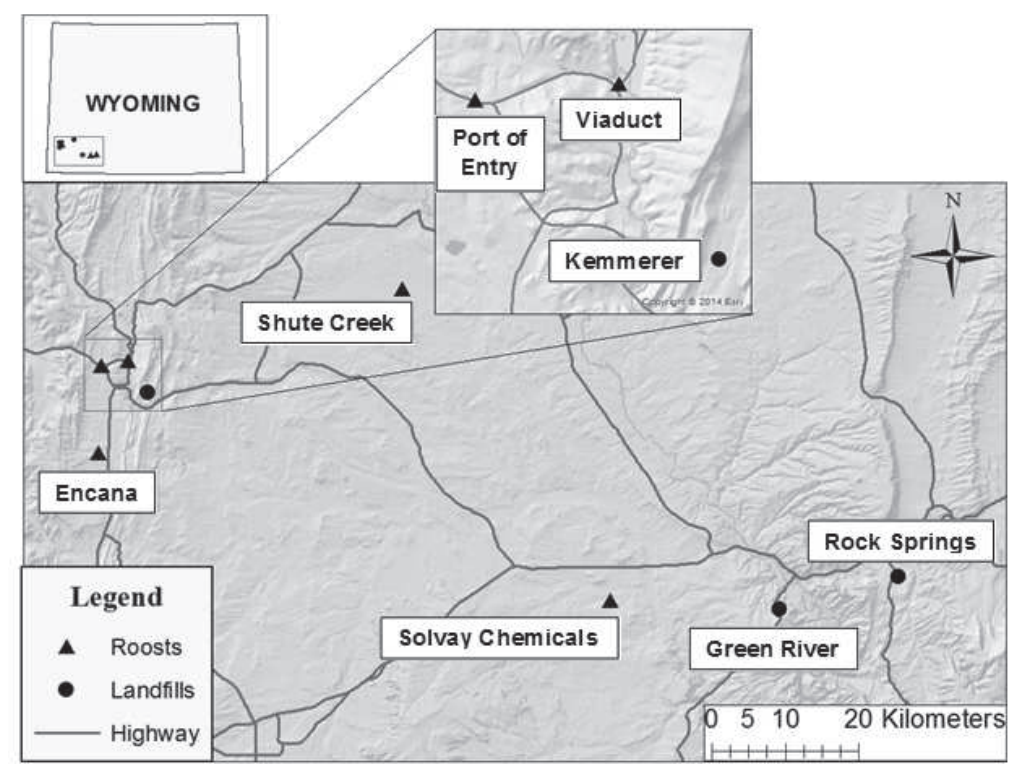

Fig. 1. Map of the study area, showing the locations of 5 anthropogenic roosts and 3 landfills used by ravens in southwestern Wyoming during the winter months (November-March) from 2013 to 2015. The map shows major highways in the region, and the Kemmerer area is enlarged to show detail.

Ravens in eastern North America are highly vagrant when spring approaches. Heinrich et al. (1994) found that only 1 of 10 radiomarked ravens captured in February were present within a $5000-\mathrm{km}^{2}$ area by mid-March when breeding pairs of ravens establish nests. In western North America, raven dispersal from areas of winter congregation has not been described.

In Wyoming, ravens congregate in large numbers during the winter at landfills and at roosts located within anthropogenic structures. To determine raven fidelity to landfills and anthropogenic roost sites, we examined weekly and daily use of these locations by ravens. We then compared raven count data between specific landfill-roost pairs and determined their connectivity. We tested how different environmental variables (e.g., day length, lunar cycle, precipitation, and temperature) explain the daily variation in numbers of ravens using landfills and anthropogenic roost sites. Finally, we looked at raven dispersal from landfills to spring locations to determine how far ravens traveled.

\section{Study Area}

We monitored raven activity at 3 landfills and 5 large (>150 ravens) roosts in southwestern
Wyoming in Lincoln and Sweetwater counties during the winter months (November-March) from 2013 to 2015 (Fig. 1). The Green River landfill was $24 \mathrm{~km}$ from the Rock Springs landfill; both of these were approximately $60 \mathrm{~km}$ from the Kemmerer landfill. No other landfills were located in these counties. The Kemmerer landfill was monitored in all 3 years, and 79\% of the ravens we captured for radio-marking were captured there. Garbage at this landfill was packaged daily into large bales, stacked in an open pit, and covered with approximately $15 \mathrm{~cm}$ of dirt. However, the sides of the newest rows of bales were left exposed and available for raven foraging. We also captured ravens at the Uinta and Rock Springs landfills and monitored these sites for raven activity after the discovery of radio-marked ravens at these locations in November 2014 and January 2015 , respectively. Both of these landfills utilized a "loose-fill" approach: garbage was dumped into an open pit, crushed with a compactor, and covered with approximately $15 \mathrm{~cm}$ of dirt 2 to 3 times a week.

Our study area in rural Wyoming lacked large groves of trees suitable for roosting in the winter months. Instead, ravens roosted at industrial sites or under bridges. To locate raven roosts, we examined numerous bridges 
and chemical plants for radio-marked ravens, questioned plant personnel and local residents, used night surveys (visual and audio), and looked for whitewash (areas of large amounts of raven fecal matter). This extensive effort revealed the location of 5 large ( $\geq 150$ ravens) roost sites during the winters of 2013-2015. During the winter of 2013, a 125-m-long viaduct in Kemmerer was used as a roost by ravens (hereafter "viaduct roost"), but a year later ravens abandoned this roost and moved to a 70-m-long railroad bridge next to the Kemmerer Port of Entry (hereafter "Port of Entry roost"). At both structures, ravens roosted below the road deck pavement on metal Ibeams, which provided overhead and horizontal protection. In the winter of 2015, the ravens at the Port of Entry roost split, and $60 \%$ to $75 \%$ of the ravens roosted at an abandoned molten sulfur-loading terminal owned by Encana, an energy corporation (hereafter "Encana roost"). The predominant roosting structures at the Encana roost were storage tanks, metal I-beams, and the metal overhead walkway. These structures were not enclosed but had horizontal protection and limited overhead protection. We monitored 2 other roosts from 2013 to 2015: the Shute Creek natural gas plant (hereafter "Shute Creek roost") and the Solvay Chemicals soda ash plant (hereafter "Solvay Chemicals roost"). At these industrial sites, ravens roosted mainly on pipe racks where heated gas was being piped in the facilities.

Our study area had a mean elevation of 2100 $\mathrm{m}$ and consisted largely of sagebrush (Artemisia spp.) plant communities. Agricultural use was limited to mainly cattle and sheep grazing across the study area; most land was managed for multiple use by the Bureau of Land Management (BLM). Oil and gas sequestration represented the highest land use activity outside of agriculture. During the winter months from 2013 to 2015, Kemmerer received an average seasonal precipitation of $6 \mathrm{~cm}$, and daily temperatures averaged $-4{ }^{\circ} \mathrm{C}$. Green River and Rock Springs received $7 \mathrm{~cm}$ of precipitation from November 2014 to March 2015; daily temperatures over this period averaged $-0.1^{\circ} \mathrm{C}$.

\section{Methods}

We captured ravens using \#3 leghold traps (Soft Catch ${ }^{\circledR}$ Coil, Oneida Victor ${ }^{\circledR}$, Euclid,
$\mathrm{OH})$ placed within landfills and near roadkills or carcasses. We captured and radio-marked 73 ravens during this study $(23,25$, and 25 during the winters of 2013, 2014, and 2015, respectively). The number of ravens known to be alive was 23 during the winter of 2013, 32 during 2014, and 34 during 2015; these include surviving ravens marked in previous years. Ravens were equipped with either a 19- or 24-g VHF backpack transmitter (Model A1135/A1140, Advanced Telemetry Systems, Isanti, MN) or a 30-g solar-powered GPS PTT transmitter (North Star Science and Technology, King George, VA) that weighed $<3 \%$ of their body weight. Mass measurements as well as age classifications (juvenile/adult) based on mouth color and plumage characteristics were taken for individuals (Kerttu 1973, Heinrich and Marzluff 1992).

Stationary data loggers (Model 4500S, Advanced Telemetry Systems) equipped with 3-element Yagi antennas (Communications Specialists, Orange, CA) recorded telemetry data for radio-marked ravens at landfills and anthropogenic roost sites on a continual basis throughout the winter months. Data loggers were systematically moved among all landfills and roosts so that all were covered during each winter. We programmed the data loggers to detect transmitter frequencies and store them for subsequent downloading. We also utilized Communications Specialists R-1000 receivers and 3-element Yagi antennas at landfills (throughout the day) and at anthropogenic roost sites (once each night after all roosting ravens were present) where data loggers were not stationed.

Ravens equipped with the GPS transmitters were monitored on a daily basis using data collected from Argos satellites. Six points per raven per day were collected at 00:00, 07:00, 10:00, 13:00, 16:00, and 19:00 Mountain Standard Time. We were able to locate ravens with GPS transmitters on $98 \%$ of the days; solar charging issues (e.g., feathers covering the solar cell) and raven behavior contributed to most of the lost fixes (2\%).

We counted ravens at the Kemmerer, Green River, and Rock Springs landfills multiple times per week to assess changes in raven numbers across time and sites. Counts were conducted every $15 \mathrm{~min}$, and surveys usually lasted from dawn until 1 to $2 \mathrm{~h}$ before dark. Counts were conducted at a predetermined 
elevated location that provided the best view of the garbage where ravens were foraging within each landfill. We determined the number of different ravens using a landfill during a day by determining the maximum number of ravens at the landfill during a particular day. This maximum count, however, needed to be adjusted to account for ravens that used the landfill sometime during that day but were not there at the time of the maximum number. We did this by determining what proportion of the radio-marked ravens that were at the landfill sometime during that day were actually present at the time of the maximum raven count. We then divided the maximum raven count by that proportion (Peebles and Conover 2017). Evening roost counts were conducted multiple times per week at the 5 roosts (viaduct, Port of Entry, Encana, Solvay Chemicals, and Shute Creek). Surveys consisted of counting individual ravens as they entered the roost or associated staging areas. Counts began 1 to $2 \mathrm{~h}$ before dusk, before all but $\leq 5 \%$ of the ravens arrived, and continued until darkness when counting was no longer possible.

We analyzed individual raven use of landfills and anthropogenic structures for roosting over time to determine fidelity at each site. We monitored radio-marked ravens weekly and recorded whether they were present or absent from the roost or landfill they used in the prior week. We also calculated the percentage of radio-marked ravens (those known to be alive and transmitting signals) that used landfills and anthropogenic roost sites on a daily basis. These percentages were calculated on days and nights when all landfills and known roost sites were monitored for radiomarked ravens. To examine connectivity of landfills and anthropogenic roost sites used by ravens, we looked at whether the number of ravens attending landfills and anthropogenic roost sites were concordant (i.e., landfill attendance and anthropogenic roost attendance increased and declined similarly) or random (i.e., no patterns were apparent). We analyzed these data using a negative binomial regression, which allows comparisons between count data that are overdispersed. We looked to see if roost counts were correlated with the numbers of ravens at landfills, and we noted which landfill-roost pairs were significant at $\alpha=0.05$. Roost count data were scant in the winter of 2012-2013 ( $n \leq 10$ counts/roost).
Therefore, roost-landfill correlations were only measured during the winters of 2013-2014 and 2014-2015.

Ravens often forage 1-2 $\mathrm{h}$ just before and 1-2 h immediately after roosting (Engel and Young 1989). To examine how raven landfill attendance changes throughout the day, we (1) grouped the number of radio-marked ravens present at the landfill hourly and (2) recorded the total number of radio-marked ravens that visited each landfill daily. We then divided the former by the latter to determine the percentages of radio-marked ravens that visited the landfill during each hour of the day.

We also examined the hourly attendance at the landfills, which was calculated from the raw count data by averaging the four 15-min counts for each hour. Each landfill's data were recorded separately. Data were available from November to March for the Kemmerer and Green River landfills, whereas data were available from January to March for the Rock Springs landfill.

From January through March 2015, we recorded behavior data during each 15-min landfill count. We classified raven activity into 3 categories: foraging, loafing, and flying. We focused most of our attention on foraging behavior, the primary behavior of interest. Ravens were considered to be foraging if they were seen swallowing garbage, inserting their bills into garbage, or competing for food with conspecifics. Loafing behavior included resting postures, such as perching, as well as maintenance behaviors, such as preening. Individuals were considered as flying anytime that the bird was airborne. We determined the percentage of ravens foraging at a landfill for each 15-min time step by dividing the number of ravens foraging at each landfill count by the total number of ravens at each landfill count. We then grouped foraging behavior data hourly, similar to the landfill count data, to see if raven behavior followed a certain time pattern (e.g., ravens foraging intensively in the crepuscular hours). Each landfill's behavior data were recorded separately. A Kruskal-Wallis test was used to detect differences in raven foraging behavior across all landfills. However, a Kruskal-Wallis test does not allow identification of which pairs of behaviors are significantly different. Pairwise comparisons of raven foraging behavior between different landfills were made using the "posthoc.kruskal.nemenyi.test" 
function in the PMCMR package, version 1.2, in $\mathrm{R}$ ( $\mathrm{R}$ Development Core Team, Vienna, Austria), which compares the differences in the mean rank sums of the different group levels (behaviors).

Environmental conditions may explain variation in the daily numbers of ravens using anthropogenic roost sites and landfills. We obtained daily lunar cycle and day length data from the Astronomical Applications Department of the United States Naval Observatory (USNO, Washington, DC). Lunar cycle (moonlight) was recorded as the fraction of the moon illuminated at midnight, Mountain Standard Time, without regard to cloud cover. Day length was recorded as the total time that any portion of the sun was above the horizon. Day length data for the project were extracted from the city closest to each anthropogenic roost site and landfill.

We obtained daily climate data from National Oceanic and Atmospheric Administration (NOAA) weather stations located within the vicinity $(<10 \mathrm{~km})$ of landfills and anthropogenic roost sites. Data obtained from these stations included daily maximum temperature $\left(\operatorname{Tmax} ;{ }^{\circ} \mathrm{C}\right)$, daily minimum temperature $\left(\right.$ Tmin; $\left.{ }^{\circ} \mathrm{C}\right)$, and daily precipitation $(\mathrm{cm})$, which was usually snow. Maximum temperatures were applied to the landfill data because they better represent the daytime temperatures when ravens are foraging. Minimum daily temperatures, in contrast, were applied to the roost data because they better represent nocturnal temperatures.

We analyzed environmental effects on the numbers of ravens attending anthropogenic roosts and landfills using negative binomial generalized linear models (GLMs) in R. Models were compared using Akaike's information criterion corrected for small sample sizes $\left(\mathrm{AIC}_{c}\right)$ and Akaike weights $\left(w_{i}\right.$; Burnham and Anderson 2002) by use of the "aictab" function in the "bbmle" package, version 1.0.17, in R; this function ranks the models using an information theoretic approach. Model averaging over a cumulative $\mathrm{AIC}_{c}$ weight of $90 \%$ was utilized when large numbers of models were competitive $\left(\Delta \mathrm{AIC}_{c}<4\right)$ or if model weights were widely distributed, and thus contained high amounts of uncertainty (Arnold 2010). Model averaging was performed using the "model.avg" function in the "MuMIn" package, $\mathrm{R}$ version 1.10 .5 , which averages over a specified subset of models based on an information criterion (in this case, $\mathrm{AIC}_{c}$ ). The model-averaged coefficients were then backtransformed to report incident rates. Before analyzing groups of covariates, we used a Pearson's correlation matrix to identify multicollinearity between pairs of variables. If $r \geq$ 0.65 , both variables in the pair were not included in the same model, but rather the one that made the most biological sense was chosen. Precipitation was modeled for landfill and roost data as a quantitative variable and a binary categorical variable (no precipitation $=$ 0 , precipitation $=1$ ) because precipitation in the study area was sporadic; $14 \%$ of roost nights and $22 \%$ of foraging days had precipitation. We used $\mathrm{AIC}_{c}$ to determine the more appropriate measure of precipitation for each dataset within our modeling scheme.

Fixed-wing telemetry flights were conducted in the spring to locate radio-marked ravens and calculate the distance from winter roost sites. We gridded an area covering approximately $23,000 \mathrm{~km}^{2}$ centered on Kemmerer, Wyoming, which was where $85 \%$ of the ravens were captured. The aircraft was equipped with two 3-element Yagi antennas mounted on the wing struts to increase detection probability, and a handheld receiver was used to locate signals transmitted from ravens. All flights $(n=6)$ but one were conducted from 15 May to 31 May. The exception was a flight that took place the last week of April 2014. Locations from GPS-marked ravens were obtained in a similar fashion. However, because these transmitters record data at specific time intervals, they were reported separately from the VHF-marked sample. GPS locations in April and May were analyzed and compared with VHF raven data.

\section{REsults}

Our sample size of radio-marked ravens was 23 during the winter of 2012-2013, 32 during 2013-2014, and 34 during 2014-2015. Use of a landfill or anthropogenic roost site was highly repeatable over time, with $70 \%$ of ravens using the same landfills and $84 \%$ of ravens using the same roosts in consecutive weeks. During the day, an average of $22 \%$ (SE 1\%) of radio-marked ravens were present at a landfill. During the evening, 68\% (SE $1 \%$ ) of radio-marked ravens were found at an 
TABLE 1. Model coefficients of negative binomial regressions between the numbers of ravens roosting at anthropogenic structures and the total numbers of raven utilizing landfills for specific roost-landfill pairs in southwestern Wyoming, USA, during the winters of 2014 and 2015 (top portion of table). The distance ( $\mathrm{km}$ ) between specific roost-landfill pairs (bottom portion of table). The sample sizes of roost counts in the winter of 2013 were small $(n<10)$; therefore, no correlations were conducted that year. We compared 264 concurrent roost and landfill counts.

\begin{tabular}{llrrr}
\hline & & & Landfill & \\
\cline { 3 - 4 } Year & Roost & Kemmerer & Green River & Rock Springs \\
\hline 2014 & Port of Entry & $6.6 \times 10^{-4 * *}$ & $*$ & $*$ \\
2014 & Shute Creek & $2.5 \times 10^{-4}$ & $*$ & $*$ \\
2014 & Solvay & $4.5 \times 10^{-4}$ & $*$ & $1.1 \times 10^{-3}$ \\
2015 & Port of Entry & $1.0 \times 10^{-3 * *}$ & $-1.0 \times 10^{-3}$ & $4.9 \times 10^{-4}$ \\
2015 & Encana & $-8.8 \times 10^{-5}$ & $8.8 \times 10^{-4}$ & $-6.9 \times 10^{-4}$ \\
2015 & Shute Creek & $2.6 \times 10^{-4}$ & $-7.5 \times 10^{-4}$ & $-6.6 \times 10^{-4}$ \\
2015 & Solvay & $2.6 \times 10^{-4}$ & $1.1 \times 10^{-3}$ & Rock Springs \\
\hline & & & Landfill & 111 \\
& & Kemmerer & Green River & 77 \\
& Roost & 7 & 98 & 39 \\
& Port of Entry & 38 & 67 & 110 \\
\hline
\end{tabular}

*Landfill not monitored that year.

**Indicates a coefficient that is significant at $\alpha=0.05$.

TABLE 2. Proportion of evenings $(N)$ that radio-marked ravens roosted at particular anthropogenic roosts sites after spending that day at certain landfills. Data were collected from 73 ravens in southwestern Wyoming, USA, 2013-2015.

\begin{tabular}{lcccccrr}
\hline & & & \multicolumn{3}{c}{ Roost } \\
\cline { 4 - 8 } Landfill & Year & $N$ & Viaduct & $\begin{array}{c}\text { POE/ } \\
\text { Encana }\end{array}$ & $\begin{array}{c}\text { Shute } \\
\text { Creek }\end{array}$ & Solvay & Unknown \\
\hline Kemmerer & 2013 & 62 & $84 \%$ & $*$ & $* *$ & $* *$ & $16 \%$ \\
Kemmerer & 2014 & 313 & $*$ & $84 \%$ & $8 \%$ & $0 \%$ & $9 \%$ \\
Kemmerer & 2015 & 381 & $*$ & $80 \%$ & $3 \%$ & $0 \%$ & $17 \%$ \\
Green River & 2015 & 48 & $*$ & $2 \%$ & $0 \%$ & $71 \%$ & $27 \%$ \\
Rock Springs & 2015 & 38 & $*$ & $0 \%$ & $0 \%$ & $66 \%$ & $34 \%$ \\
\hline
\end{tabular}

*Roost not active that year

$* *$ Roost not monitored that year

anthropogenic roost site. We analyzed 15 landfill-roost pairs during the 2014 and 2015 winters. Out of 15 analyses, there were only 2 negative binomial regressions that were significant at $\alpha=0.05$; these were between the Kemmerer landfill and the Port of Entry roost. The other coefficients were positive, indicating that the number of ravens at roosts and local landfills changed concurrently (Table 1; Fig. 2). Radio-marked ravens tended to use the anthropogenic roost site closest to the landfill where they were foraging (Table 2).

We conducted 5004 15-min counts at landfills and recorded $4620 \mathrm{~h}$ of radio-telemetry data at landfills from November to March of 2013-2015. At the Kemmerer landfill, raven numbers (Fig. 3) and the percentage of radiomarked ravens at the landfill (Fig. 4) increased slowly throughout the day. At the Green River and Rock Springs landfills, raven numbers were highest in the morning, and dropped afterwards; similar patterns were observed in the hourly percentages of radio-marked ravens at these 2 landfills.

We recorded behavioral observations of ravens over 2349 15-min landfill counts from January through March 2015 (Fig. 5). Loafing $(\bar{x}=54 \%)$ was the most common behavior at landfills, followed by foraging $(\bar{x}=28 \%)$ and flying $(\bar{x}=18 \%)$. The percentages of ravens foraging were significantly different across landfills (Kruskal-Wallis $\chi^{2}=198.67, P<$ 0.01). Post hoc comparisons revealed that the Kemmerer landfill had more foraging $(\bar{x}=$ $36 \%)$ compared to the Green River $(\bar{x}=11 \%$, $P<0.01)$ and Rock Springs landfills $(\bar{x}=24 \%$; 
2013-2014 Kemmerer landfill-roost comparisons

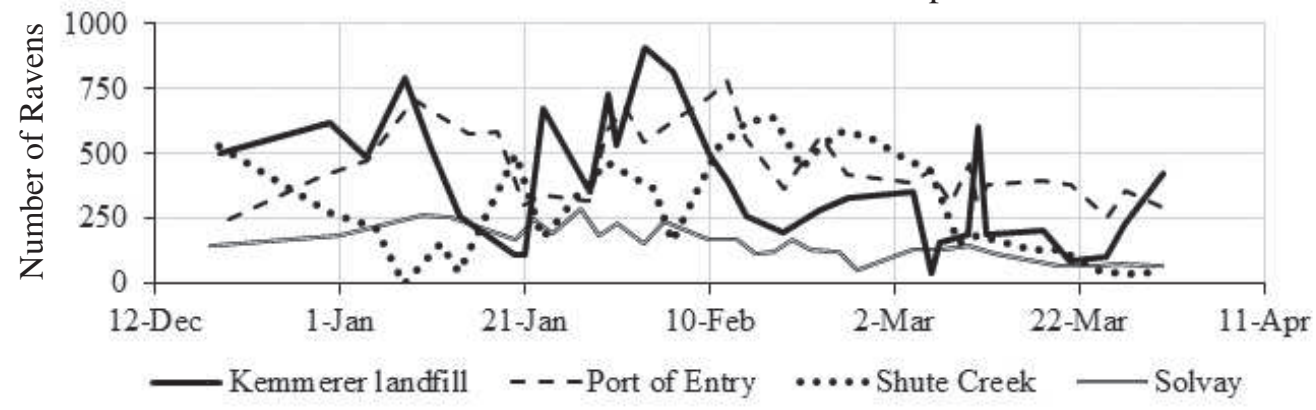

2014-2015 Kemmerer landfill-roost comparisons

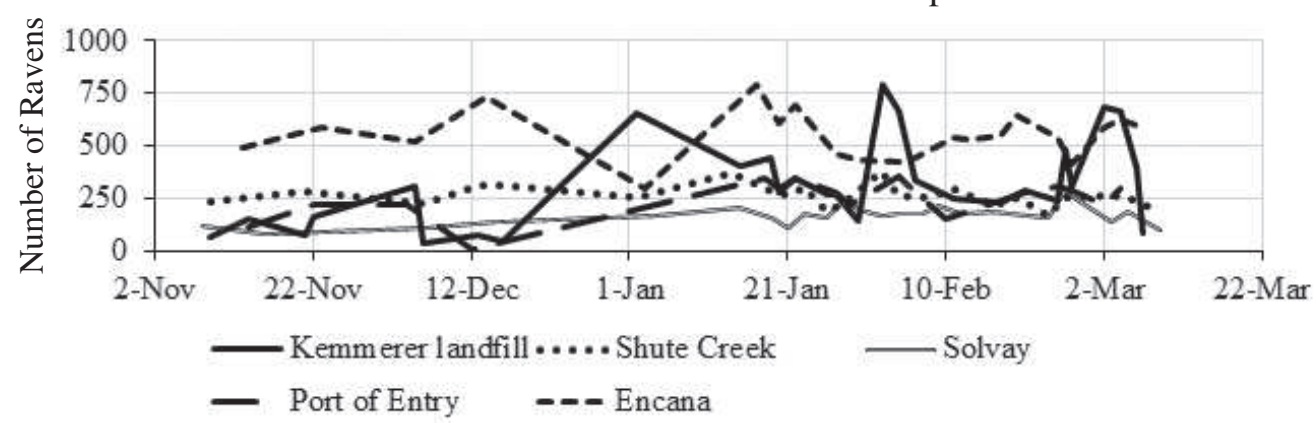

2014-2015 Green River landfill-roost comparisons

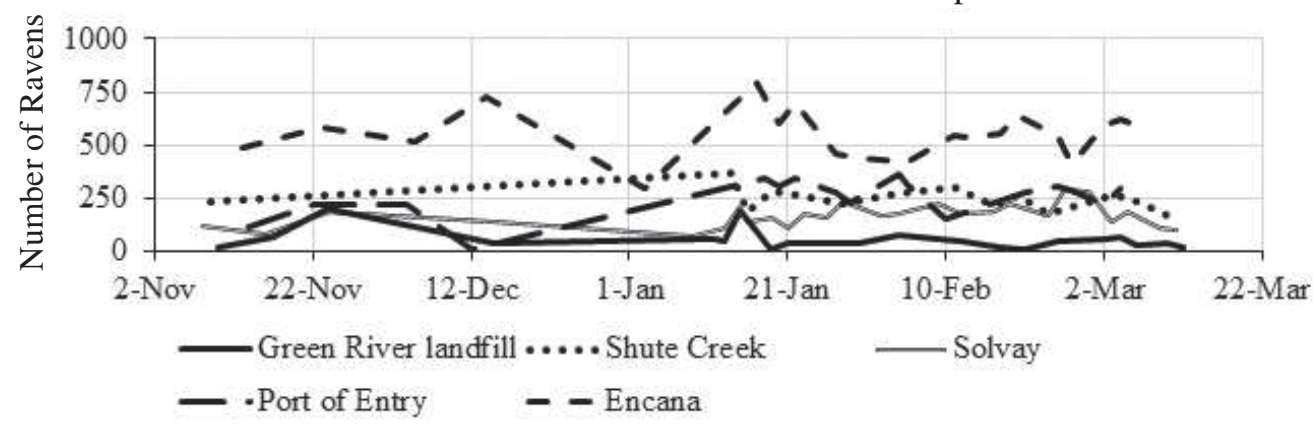

2014-2015 Rock Springs landfill-roost comparisons

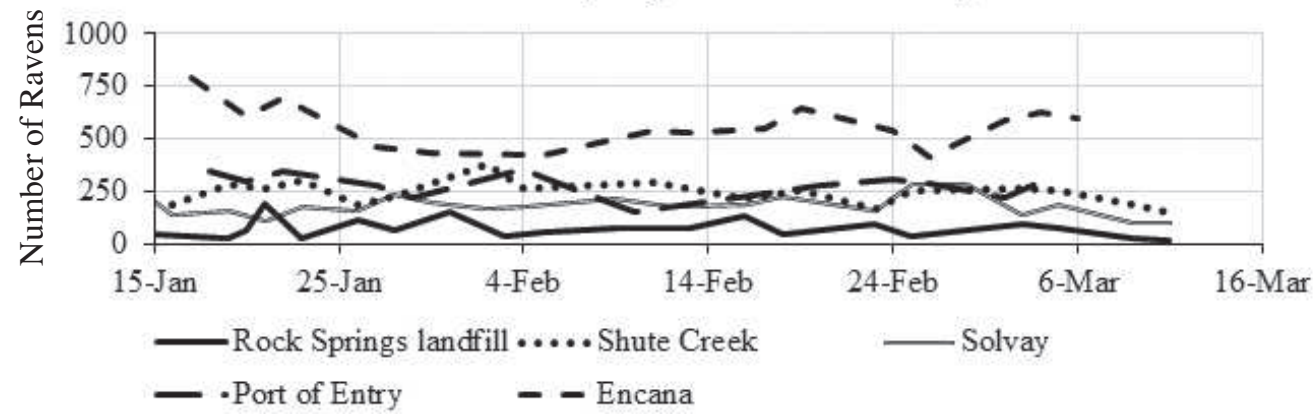

Fig. 2. Estimated numbers of ravens attending the Kemmerer, Green River, and Rock Springs landfills, and the observed numbers of ravens roosting at anthropogenic roost sites during the winter of 2013-2014 on concurrent days in southwestern Wyoming, USA. 


\section{Kemmerer landfill}
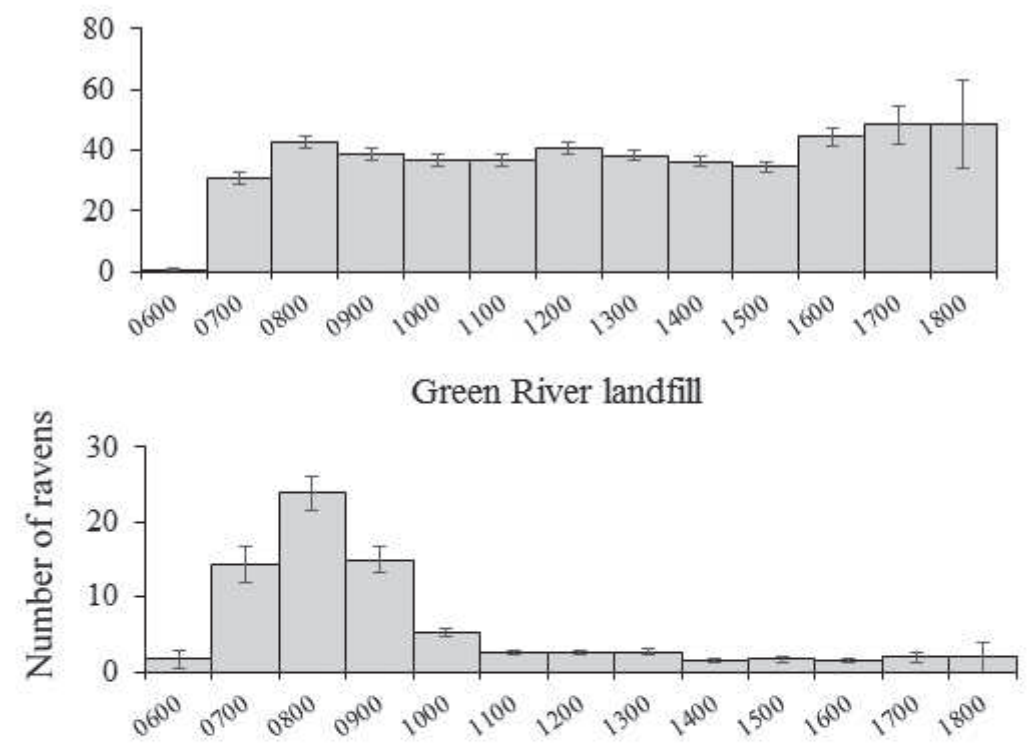

Rock Springs landfill

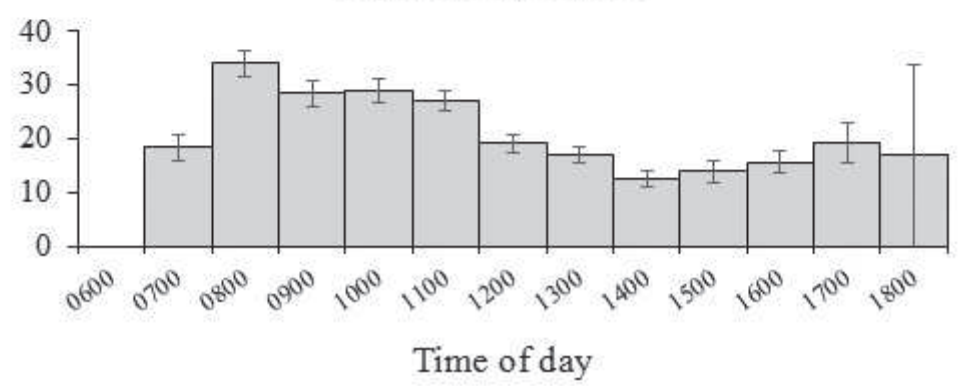

Fig. 3. Hourly mean of numbers of ravens utilizing landfills during the winter in southwestern Wyoming, USA, 2013-2015. Data were available for the Kemmerer landfill and Green River landfill from November through March; the Rock Springs landfill had data from January through March. Data were obtained from 5004 landfill count surveys. Error bars represent standard error $(\mathrm{SE})$.

$P<0.01)$. Hourly comparisons of foraging behavior show different behavioral trends among landfills. A higher proportion of ravens were foraging during the morning than during the rest of the day at the Green River and Rock Springs landfills, but not at the Kemmerer landfill (Fig. 5). The average percentages of ravens foraging varied significantly among landfills later in the morning and in the afternoon. The Kemmerer landfill remained constant in the amount of foraging observed, the Green River landfill saw rapid declines in foraging, and the Rock Springs landfill saw declines in foraging during midday, with a substantial increase in foraging at the end of the day.
We analyzed the effects of environmental variables on raven numbers at landfills for $130 \mathrm{~d}$ summed across all landfills. With regard to the landfill attendance model, the qualitative precipitation model had an $\mathrm{AIC}_{c}$ score that was within 4 of the $\mathrm{AIC}_{c}$ of the quantitative precipitation model, so we used the former for further analysis (Burnham and Anderson 2002). The top $12 \mathrm{AIC}_{c}$-selected environmental models were highly competitive and contained $90 \%$ of the model weight (Table 3); therefore, we employed model averaging. Temperature had negative effects on numbers of ravens attending landfills (Table 4); an increase of $1{ }^{\circ} \mathrm{C}$ in temperature resulted in a $7 \%(95 \%$ CI $4 \%$ to $10 \%$ ) decrease in ravens using 


\section{Kemmerer landfill}
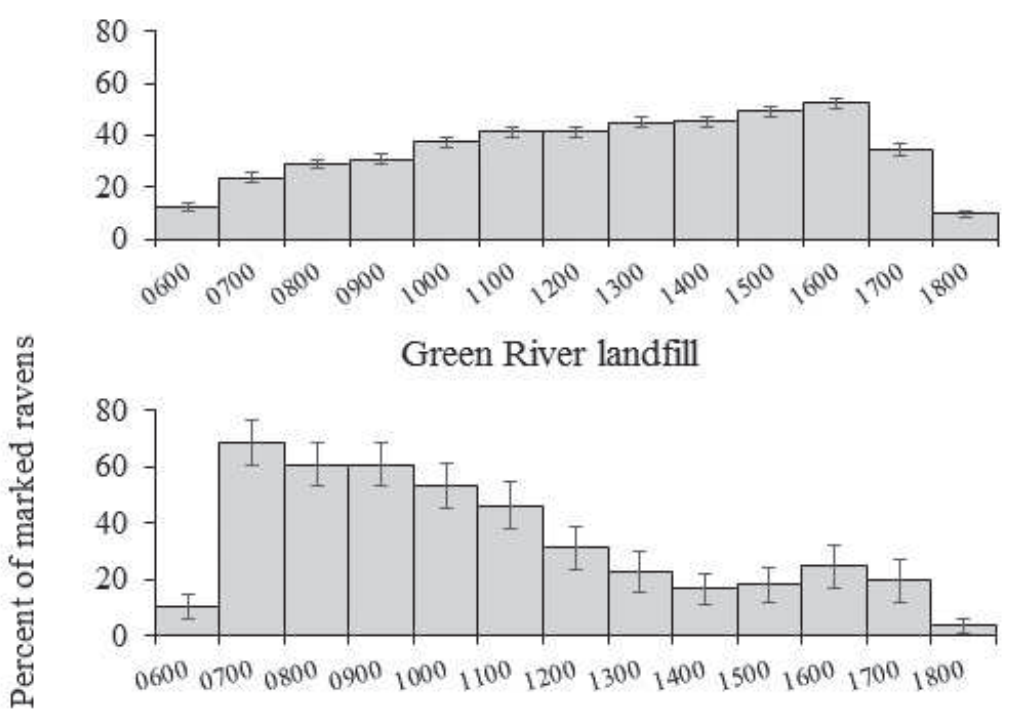

Rock Springs landfill

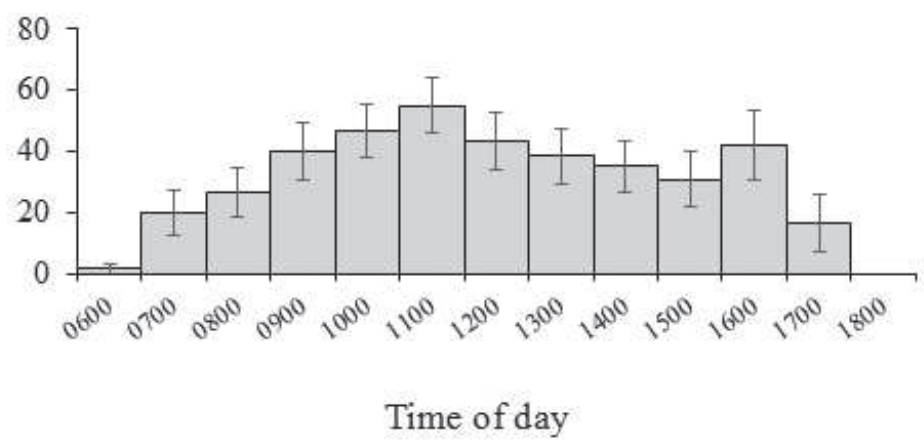

Fig. 4. Hourly mean of percentages of radio-marked ravens out of the daily total number of marked ravens that visited landfills during the winter in southwestern Wyoming, USA, 2013-2015. Data were available for the Kemmerer and Green River landfills from November through March; the Rock Springs landfill had data from January through March. Data were obtained from $4620 \mathrm{~h}$ of telemetry observations of 73 ravens. Error bars represent standard error (SE).

landfills. Moonlight, day length, and precipitation were uninformative predictors of the number of ravens utilizing landfills (Table 4).

We analyzed the effects of environmental variables on raven numbers at anthropogenic roost sites for 241 roost nights. The qualitative precipitation model for roost attendance had an $\mathrm{AIC}_{c}$ score that was within 4 of the $\mathrm{AIC}_{c}$ of the quantitative precipitation model, so we used the former for further analysis (Burnham and Anderson 2002). The top $7 \mathrm{AIC}_{c}$-selected environmental models were highly competitive and contained $90 \%$ of the model weight (Table 5); therefore, we employed model averaging. Minimum temperature had a negative relationship with number of ravens roosting at anthropogenic structures (Table 6); a decrease of $1{ }^{\circ} \mathrm{C}$ in temperature resulted in a $2 \%(95 \%$ CI $1 \%$ to $4 \%$ ) increase in the number of ravens roosting at these locations. Moonlight, day length, precipitation, and the interaction between precipitation and minimum temperature were uninformative predictors of roost size at anthropogenic structures (Table 6).

We obtained 51 spring dispersal locations of VHF-marked ravens from 2013 to 2015 (Fig. 6). VHF-marked ravens dispersed, on average, $38 \mathrm{~km}(\mathrm{SE} 4 \mathrm{~km})$ from landfills where they were captured and spent the winter; $75 \%$ dispersed $<50 \mathrm{~km}$ from their capture locations. 

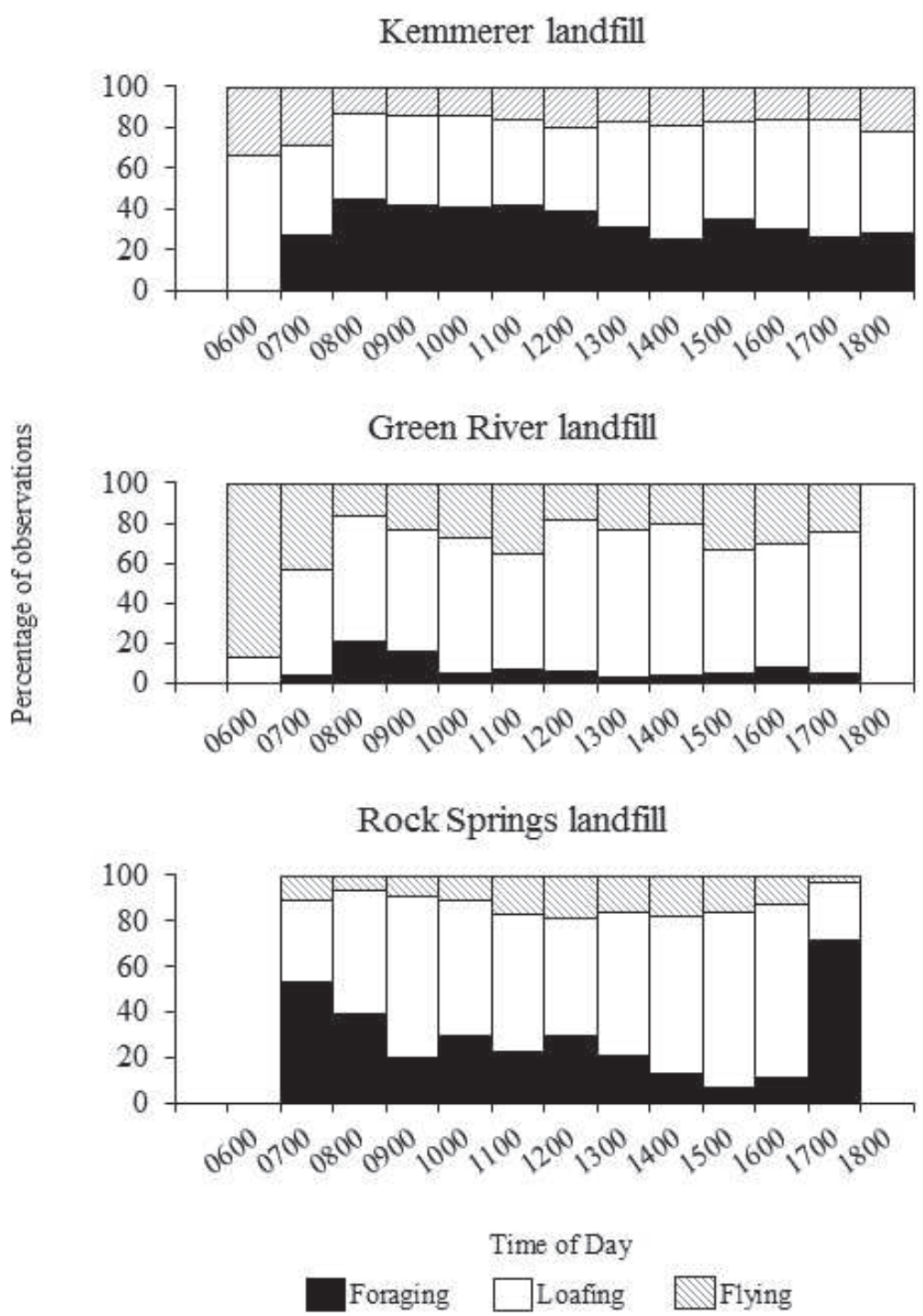

Fig. 5. Hourly percentages of ravens foraging, loafing, and flying out of the total number of ravens present at landfill counts at 3 landfills during the winter months in southwestern Wyoming, USA, in 2015. Data were available from January through March; behavioral observations were recorded for 2349 landfill count surveys.

The longest dispersal distance recorded for a VHF-marked raven was $98 \mathrm{~km}$. We obtained 1383 locations from 5 GPS-marked ravens during the spring (Fig. 7). These locations were an average of $39 \mathrm{~km}(\mathrm{SE}=1 \mathrm{~km})$ from the landfills where the ravens were captured; $75 \%$ of GPS locations were within $60 \mathrm{~km}$ of the landfills where they were captured. The furthest recorded distance from the point of capture for a GPS-marked raven was $151 \mathrm{~km}$.

\section{Discussion}

Ravens regularly visited landfills they attended the week before; however, only $22 \%$ of the radio-marked individuals were found at landfills on any given day. Other foraging sites, including paved highways, towns, and the numerous livestock operations within the study site, provided adequate food resources for ravens. Several studies have shown that small mammals and the remains of larger 
TABLE 3. Top 16 negative binomial generalized linear models assessing the effect of climatic and rhythmic variables on the daily numbers of ravens utilizing 3 landfills in southwestern Wyoming, USA, 2013-2015. The daily numbers of ravens utilizing landfills were calculated by dividing the maximum landfill count by the proportion of radio-marked ravens utilizing the landfill on that day that were present at the time of the count. Models were compared with Akaike's information criterion adjusted for small sample sizes $\left(\mathrm{AIC}_{c}\right)$ and Akaike weights $\left(w_{i}\right)$. Count data were obtained for $130 \mathrm{~d}$ summed across all landfills.

\begin{tabular}{lcccc}
\hline Model & $\mathrm{AIC}_{c}$ & $\Delta \mathrm{AIC}_{c}$ & $k$ & $w_{i}$ \\
\hline Precipitation + Tmax & 1601.0 & 0.0 & 3 & 0.17 \\
Moonlight + precipitation + Tmax & 1601.0 & 0.1 & 4 & 0.17 \\
Day length + Tmax & 1601.3 & 0.3 & 3 & 0.15 \\
Day length + moonlight + Tmax & 1602.5 & 1.6 & 4 & 0.08 \\
Day length + precipitation + Tmax & 1602.7 & 1.8 & 4 & 0.07 \\
Day length + moonlight + precipitation + Tmax & 1602.7 & 1.8 & 5 & 0.07 \\
Precipitation $\times$ Tmax & 1602.8 & 1.8 & 3 & 0.07 \\
Moonlight + (precipitation $\times$ Tmax) & 1602.9 & 2.0 & 4 & 0.07 \\
Tmax & 1602.9 & 2.0 & 2 & 0.07 \\
Day length + Tmax & 1604.2 & 3.2 & 3 & 0.04 \\
Day length + (precipitation $\times$ Tmax) & 1604.6 & 3.6 & 4 & 0.03 \\
Day length + moonlight + (precipitation $\times$ Tmax) & 1604.7 & 3.7 & 6 & 0.03 \\
Precipitation & 1618.2 & 17.3 & 2 & 0.00 \\
Day length + precipitation & 1619.3 & 18.3 & 3 & 0.00 \\
Moonlight + precipitation & 1620.2 & 19.3 & 3 & 0.00 \\
Intercept-only & 1622.3 & 21.3 & 1 & 0.00 \\
\hline
\end{tabular}

TABLE 4. Parameter estimates for the top $\mathrm{AIC}_{c}$-selected model explaining environmental variables that influence the daily number of ravens utilizing 3 landfills in southwestern Wyoming, USA, 2013-2015. The daily numbers of ravens utilizing landfills were calculated by dividing the maximum landfill count by the proportion of radio-marked ravens utilizing the landfill on that day that were present at the time of the count. Count data were obtained for 130 landfill days.

\begin{tabular}{lcccc}
\hline Variable & Estimate & SE & 95\% Lower CI & 95\% Upper CI \\
\hline Intercept & 5.160 & 0.573 & 4.030 & $6.291^{*}$ \\
Day length & 1.711 & 2.316 & -2.514 & 5.937 \\
Moonlight & 0.370 & 0.228 & -0.082 & 0.821 \\
Precipitation & 0.347 & 0.229 & -0.105 & 0.799 \\
Tmax & -0.072 & 0.014 & -0.101 & $-0.042^{*}$ \\
Precipitation $\times$ Tmax & 0.023 & 0.037 & -0.050 & 0.097 \\
\hline
\end{tabular}

*Denotes parameter estimates where the $95 \%$ confidence intervals do not include zero.

TABLE 5. Top 15 binomial generalized linear models assessing the effects of environmental variables on the numbers of ravens roosting at 5 anthropogenic roost sites in southwestern Wyoming, USA, 2013-2015. Models were compared with Akaike's information criterion adjusted for small sample sizes $\left(\mathrm{AIC}_{c}\right)$ and Akaike weights $\left(w_{i}\right)$. Data were collected for 241 roost nights.

\begin{tabular}{lcccc}
\hline Model & $\mathrm{AIC}_{c}$ & $\Delta \mathrm{AIC}_{c}$ & $k$ & $w_{i}$ \\
\hline Tmin & 3193.6 & 0.0 & 2 & 0.29 \\
Precipitation + Tmin & 3194.5 & 0.9 & 3 & 0.18 \\
Moonlight + Tmin & 3195.6 & 2.0 & 3 & 0.11 \\
Day length + Tmin & 3195.7 & 2.1 & 3 & 0.10 \\
Precipitation $\times$ Tmin & 3196.5 & 3.0 & 4 & 0.07 \\
Precipitation + moonlight + Tmin & 3196.6 & 3.0 & 4 & 0.07 \\
Day length + precipitation + Tmin & 3196.6 & 3.0 & 4 & 0.06 \\
Day length + Tmin & 3197.7 & 4.1 & 3 & 0.04 \\
Moonlight + (precipitation $\times$ Tmin) & 3198.6 & 5.0 & 4 & 0.02 \\
Day length + (precipitation $\times$ Tmin) & 3198.6 & 5.0 & 4 & 0.02 \\
Daylength + moonlight + precipitation + Tmin & 3198.7 & 5.1 & 5 & 0.02 \\
Daylength + moonlight + (precipitation $\times$ Tmin) & 3200.7 & 7.1 & 6 & 0.01 \\
Intercept-only & 3202.2 & 8.6 & 1 & 0.00 \\
Precipitation & 3203.6 & 10.0 & 2 & 0.00 \\
Day length & 3203.7 & 10.2 & 2 & 0.00 \\
\hline
\end{tabular}


TABLE 6. Model-averaged parameter estimates for the top 2 models containing $90 \%$ of the $\mathrm{AIC}_{c}$ weight for environmental variables influencing the numbers of ravens roosting at 5 anthropogenic roost sites in southwestern Wyoming, USA, 2013-2015. Data were collected for 241 roost nights.

\begin{tabular}{lrccc}
\hline Variable & Estimate & SE & 95\% Lower CI & 95\% Upper CI \\
\hline Intercept & 5.557 & 0.223 & 5.086 & $6.029^{*}$ \\
Day length & -0.082 & 1.053 & -2.157 & 1.992 \\
Moonlight & 0.028 & 0.117 & -0.202 & 0.257 \\
Precipitation & 0.134 & 0.139 & -0.139 & 0.407 \\
Tmin & -0.023 & 0.007 & -0.036 & $-0.009^{*}$ \\
Precipitation $\times$ Tmin & 0.005 & 0.018 & -0.030 & 0.039 \\
\hline
\end{tabular}

*Denotes parameter estimates where the $95 \%$ confidence intervals do not include zero.

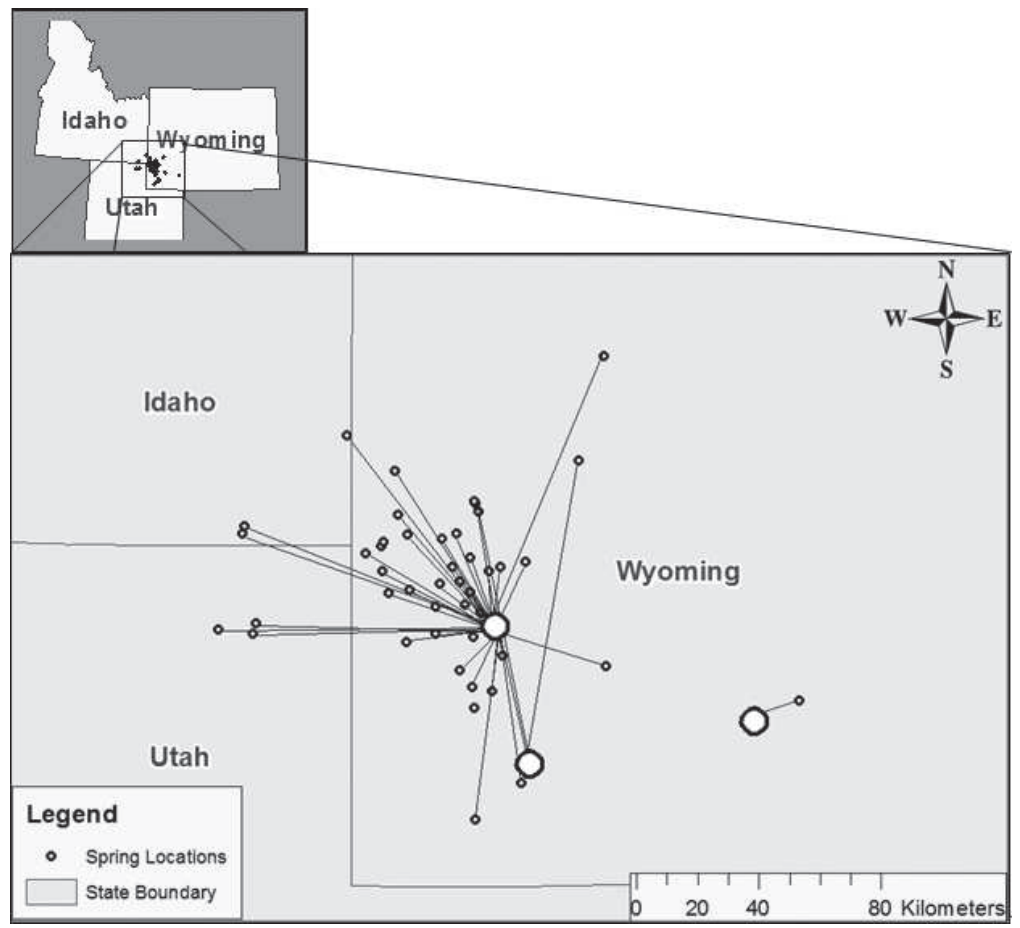

Fig. 6. Spring dispersal locations $(n=51)$ for very high frequency $(\mathrm{VHF})$ radio-marked ravens captured in southwestern Wyoming, USA, in 2013-2015. The 3 large open circles represent capture locations. Locations were obtained via radiotelemetry in a fixed-wing airplane equipped with dual 3-element Yagi antennas mounted on the wing struts. Each radio-marked raven was located once each spring.

mammals represent larger proportions of food items in raven diets than garbage (Temple 1974, Harlow et al. 1975, Engel and Young 1989, Kristan et al. 2004). Ravens regularly visited anthropogenic roost sites they attended the week before, and $68 \%$ of the radio-marked sample was found at these sites nightly. This may be reflective of the low availability of alternate roosting substrate. Elsewhere in North America, large raven roosts $(>100$ ravens) have been found in natural substrate, such as trees and cliffs (Cushing 1941, Temple
1974, Lucid and Conner 1974, Heinrich 1988). In our study area, which is predominantly sagebrush, large stands of trees and cliffs suitable for roosting are rare and distant from major food sources. Therefore, bridges and industrial sites represent the most suitable roosting structures for large numbers of ravens during the winter. Ravens in Idaho are known to use transmission towers (Engel et al. 1992). Similar transmission lines are found within $15 \mathrm{~km}$ of the Kemmerer landfill and $25 \mathrm{~km}$ of the Rock Springs landfill; however, 


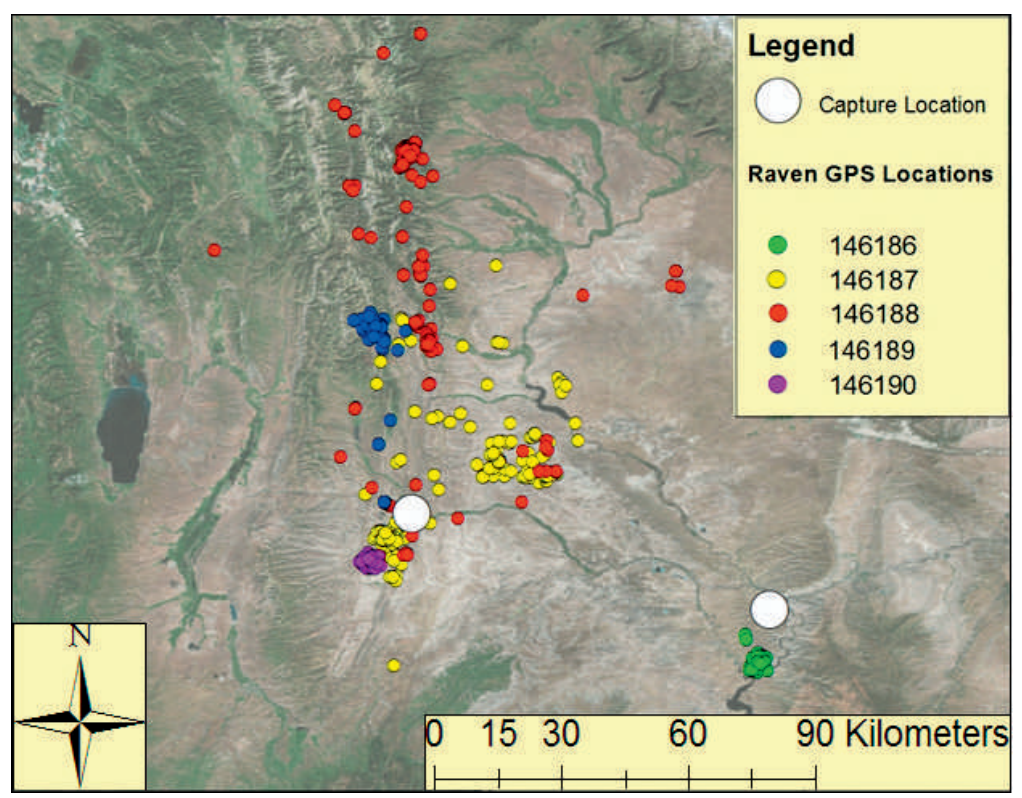

Fig. 7. Spring dispersal locations $(n=1383)$ for 5 global positioning system (GPS) radio-marked ravens captured in southwestern Wyoming, USA, in 2015. Locations were obtained at 07:00, 10:00, 13:00, 16:00, 19:00, and 24:00. GPS points were obtained in April and May to correspond to VHF-marked raven locations. Raven 146186 was captured at the Green River landfill (lower right capture location), whereas the other 4 ravens were captured at the Kemmerer landfill.

ravens were never observed roosting on them. Also, social interactions are frequent at roosting sites (Marzluff et al. 1996, Wright et al. 2003); therefore, the social aspect of roosts may serve to concentrate ravens at locations where there is adequate room for many ravens.

Landfill use by ravens, for the most part, was not connected to raven use of anthropogenic structures for roosting in southwestern Wyoming; there was no correlation between the number of roosting birds and the number of ravens attending local landfills for 13 of 15 landfill-roost pairs. Marzluff et al. (1996) and Wright et al. (2003) demonstrated that roosts are mobile information centers for determining the location of carcasses, which are sporadically distributed in space and time. Landfills, in contrast, are dependable food sources that remain in the same location; ravens likely do not need to constantly gather landfill information from roost mates. However, there was a significant, positive relationship between the Kemmerer landfill and the Port of Entry roost in the 2014 and 2015 winters, suggesting that there is a connection between the 2 sites. The Kemmerer landfill was used heavily in the latter part of the day, but few ravens were foraging late in the afternoon. During roost counts at the Port of Entry, we observed that $50 \%-75 \%$ of the ravens coming to the roost were in a flight path that was in direct line with the Kemmerer landfill. We hypothesize that this landfill was used as a staging area for ravens as they congregated before roosting at night. In contrast, all other landfills, which were $>10 \mathrm{~km}$ from the nearest anthropogenic roost site, did not see increases in ravens at the end of the day.

Environmental patterns affected how often ravens used landfills for foraging and anthropogenic structures for roosting; raven use of these sites increased when temperatures decreased. Although we could not measure snowfall directly, we included an interaction between temperature and precipitation, which was not a significant predictor of raven numbers at either location. Studies in western North America have found that use of landfills increases with increasing snow depth (Dorn 1972, Preston 2005), which is likely due to ravens having difficulty locating food items, such as carcasses from roadkill, that are concealed by snow (Heinrich 1988). Southwestern 
Wyoming does have snowfall in the wintertime, but it is infrequent and does not persist at lower elevations. However, freezing temperatures could still limit raven accessibility to carcasses; frozen carcasses not scavenged by other carnivores are difficult for ravens to tear apart. In contrast, garbage at the landfills often was unfrozen.

Roosting in large numbers (>150 ravens) in protected and/or heated locations may be a way for ravens to conserve heat. Two of our documented roosts had heat sources, and ravens roosted close to the heated elements in roosts during winter. In the other 3 unheated roost sites, ravens were observed roosting shoulder to shoulder. In Alaska, oil field workers interviewed in Alaska's North Slope about raven behavior reported that ravens were often near heated structures, and $71 \%$ of the workers reported heavy use of processing facilities by ravens in the winter (Backensto 2010). One smaller raven roost in an abandoned building ( $\bar{x}=72$ ravens) in eastern Canada was used by more ravens when windchill increased during the winter (Watts et al. 1991). Therefore, it appears that winter weather increases raven use of anthropogenic structures with shelter or heat for roosts.

Dispersal distances of ravens leaving winter locations in this study $(\bar{x}=38 \mathrm{~km})$ were significantly less than band recovery distances for wintering ravens in Iceland $(\bar{x}=151 \mathrm{~km}$; Skarphédinsson et al. 1990) and Greenland (median distance $=30,70$, and $73 \mathrm{~km}$ for 3 study sites; Restani et al. 2001). This short dispersal distance suggests that most ravens in southwestern Wyoming seek local roosts for the winter.

Anthropogenic resources have allowed raven numbers to increase in recent decades (Leu et al. 2008, Sauer et al. 2011) by increasing survival and chick production (Webb et al. 2004, Kristan and Boarman 2007). In sagebrush scrub habitats, raven nesting ecology is tied to use of anthropogenic resources, such as transmission towers and cell towers (Coates et al. 2014, Howe et al. 2014); such activities are important when considering raven management activities in conjunction with the protection of other species, like the Greater Sage-Grouse. We found that the winter ecology of ravens in these ecosystems is directly linked to anthropogenic resources as well. Winter is a stressful time for ravens, and use of anthropogenic roost sites and landfills likely improves a raven's probability of surving the winter (Conover and Roberts 2016). Thus, raven populations subsidized in the winter by anthropogenic resources will likely continue to increase if left unchecked.

Ravens depredate more sage-grouse eggs and chicks than any other predator (Conover and Roberts 2017). This depredation is severe enough that it has contributed to the decline of sage-grouse numbers over the last century (Conover and Roberts 2016, Peebles et al. 2017). In this study, we found that ravens do not disperse far from their winter roosts. This suggests that one way to reduce local problems involving ravens would be to locate roosts and target management efforts at the roosts during the winter.

\section{ACKNOWLedgments}

We thank the Anadarko Petroleum Corporation, Lincoln County Predator Management Board, Predatory Animal District of Sweetwater County, South Central Wyoming Local SageGrouse Work Group, Southwest Wyoming Local Sage-Grouse Working Group, Uinta County Predator Management Board, Utah Agricultural Experiment Station (UAES), Wyoming Animal Damage Management Board, Wyoming Game and Fish Department, and Wyoming Wildlife and Natural Resources Trust. Many thanks go to John Knoll (Exxon Mobile Shute Creek Facility), Tim Brown (Solvay Chemicals), Scott Wakeman (Kemmerer landfill), Linda Roosa (Green River landfill), and the Rock Springs landfill staff for providing access to these locations. A special thanks goes to Ted Jensen (USDA/APHIS WS), who piloted the aircraft for spring telemetry locations. Raven capture and marking methods were approved by the Institutional Animal Care and Use Committee of Utah State University (Protocol number 2031), the U.S. Fish and Wildlife Service (banding permit \#21175), and the Wyoming Game and Fish Department (Chapter 33 Permit \#657). This research was approved by UAES as journal paper number 8847.

\section{Literature Cited}

ARNOLD, T.W. 2010. Uninformative parameters and model selection using Akaike's information criterion. Journal of Wildlife Management 74:1175-1178. 
Backensto, S.A. 2010. Common Ravens in Alaska's North Slope oil fields: an integrated study using local knowledge and science. Master's thesis, University of Alaska Fairbanks, Fairbanks, AK.

BoARman, W.I. 1993. When a native predator becomes a pest: a case study. Pages 191-206 in S.K. Majumdar, E.W. Miller, D.E. Miller., E.K. Brown, J.R. Pratt, and R.F. Schmalz, editors, Conservation and resource management. Pennsylvania Academy of Science. Philadelphia, PA.

BoARman, W.I. 2003. Managing a subsidized predator population: reducing Common Raven predation on desert tortoises. Environmental Management 32: 205-217.

Boarman, W.I., and K.H. Berry. 1995. Common Ravens in the southwestern United States, 1968-92. Pages 73-75 in E.L. LaRoe, G.S. Farris, and C.E. Puckett, editors, Our living resources. U.S. Department of the Interior, National Biological Service, Washington, DC.

Brown, R.N. 1974. Aspects of vocal behavior of the raven (Corvus corax) in interior Alaska. Master's thesis, University of Alaska, Fairbanks, AK.

Burnham, K.P., AND D.R. Anderson. 2002. Model selection and multimodal inference: a practical information-theoretic approach. 2nd edition. Springer-Verlag, New York, NY.

Coates, P.S., J.W. Connelly, and D.J. Delehanty. 2008. Predators of Greater Sage-Grouse nests identified by video monitoring. Journal of Field Ornithology 79:421-428.

Coates, P.S., K.B. Howe, M.L. Casazza, and D.J. DeleHANTY. 2014. Landscape alterations influence differential habitat use of nesting buteos and ravens within sagebrush ecosystem: implications for transmission line development. Condor 116:341-356.

Conover, M.R., And A.J. Roberts. 2016. Declining populations of Greater Sage-Grouse: where and why. Human-Wildlife Interactions 10:217-229.

Conover, M.R., And A.J. Roberts. 2017. Predators, predator control, and sage-grouse: a review. Journal of Wildlife Management 81:7-15.

Cotterman, V., and B. Heinrich. 1993. A large temporary roost of Common Ravens. Auk 110:395.

Cushing, J.E. 1941. Winter behavior of ravens at Tomales Bay, California. Condor 43:103-107.

Dorn, J.L. 1972. The Common Raven in Jackson Hole, Wyoming. Master's thesis, University of Wyoming, Laramie, WY.

Engel, K.A., AND L.S. Young. 1989. Spatial and temporal patterns in the diet of Common Ravens in southwestern Idaho. Condor 91:372-378.

Engel, K.A., L.S. Young, J.A. Roppe, C.P. Wright, And M. Mulrooney. 1993. Controlling raven fecal contamination of transmission line insulators. Pages 2-14 in J.W. Huchabee, editor. Proceedings of the International Workshop on Avian Interactions with Utility Structures. Electric Power Research Institute, Miami, FL.

Engel, K.A., L.S. Young, K. Steenhof, J.A. Roppe, And M.N. Kochert. 1992. Communal roosting of Common Ravens in southwestern Idaho. Wilson Bulletin 104:105-121.

Harlow, R.F., R.G. Hooper, D.R. Chamberlain, and H.S. Crawford. 1975. Some winter and nesting season foods of the Common Raven in Virginia. Auk 92:298-306.
HeinRICH, B. 1988. Winter foraging at carcasses by three sympatric corvids, with emphasis on recruitment by the raven, Corvus corax. Behavioral Ecology and Sociobiology 23:141-156.

Heinrich, B., D. Kaye, T. Knight, and K. Schaumburg. 1994. Dispersal and association among Common Ravens. Condor 96:545-551.

Heinrich, B., and J. Marzluff. 1992. Age and mouth color in Common Ravens. Condor 94:549-550.

Howe, K.B., P.S. Coates, and D.J. Delehanty. 2014. Selection of anthropogenic features and vegetation characteristics by nesting Common Ravens in the sagebrush ecosystem. Condor 116:35-49.

Kerttu, M.E. 1973. Aging techniques for the Common Raven (Corvus corax principalis) Ridgeway. Master's thesis, Michigan Technical University, Houghton, MI.

Kristan, W.B., III, and W.I. Boarman. 2007. Effects on anthropogenic developments on Common Raven nesting biology in the west Mojave Desert. Ecological Applications 17:1703-1713.

Kristan, W.B., III, W.I. Boarman, and J.J. Crayon. 2004. Diet composition of Common Ravens across the urban-wildland interface of the West Mojave Desert. Wildlife Society Bulletin 32:244-253.

Larsen, K.H., AND J.H. Dietrich. 1970. Reduction of a raven population on lambing grounds with DRC1339. Journal of Wildlife Management 34:200-204.

LeU, M., S.E. Hanser, and S.T. KNICK. 2008. The human footprint in the West: a large-scale analysis of anthropogenic impacts. Ecological Applications 18: 1119-1139.

LinZ, G.M., C.E. KNitTle and R.E. Johnson. 1990. Ecology of corvids in the vicinity of the Aliso Creek California Least Tern colony, Camp Pendleton, California. Bird Section Research Report 450, Denver Wildlife Research Center, Denver, CO.

LuCID, V.J., AND R.N. ConNer. 1974. A communal Common Raven roost in Virginia. Wilson Bulletin 86:82-83.

Marzluff, J.M., and B. Heinrich. 1991. Foraging by Common Ravens in the presence and absence of territory holders: an experimental analysis of social foraging. Animal Behaviour 42:755-770.

Marzluff, J.M., B. Heinrich, and C.H. Marzluff. 1996. Roosts are mobile information centres. Animal Behaviour 51:89-103.

Merrell, R.J. 2012. Some successful methods to mitigate conflicts caused by Common Ravens in an industrial environment. Human-Wildlife Interactions 6:339-343.

Peebles, L.W., M.R. Conover, and J.B. Dinkins. 2017. Adult sage-grouse numbers rise following raven removal or an increase in precipitation. Wildlife Society Bulletin 41:471-478.

Preston, M.I. 2005. Factors affecting winter roost dispersal and daily behavior of Common Ravens (Corvus corax) in southwestern Alberta. Northwestern Naturalist 86:123-130.

Restani, M., J.M. Marzluff, and R.E. Yates. 2001. Effects of anthropogenic food sources on movements, survivorship, and sociality of Common Ravens in the Arctic. Condor 103:399-404.

Sauer, J.R., J.E. Hines, J.E. Fallon, K.L. Pardieck, D.J. ZIOLKOWSKI JR., AND W.A. LINK. 2011. The North American Breeding Bird Survey, results and analysis 1966-2010. Version 12.07.2011. U.S. Geological Survey Patuxent Wildlife Research Center, Laurel, MD. 
Skarphédinsson, K.H., Ó. Nielsen, S. Thórisson, S. Thorstensen, and S.A. Temple. 1990. Breeding biology, movements, and persecution of ravens in Iceland. Acta Naturalia Islandica 33:1-45.

Spencer, J.O., JR. 2002. DRC-1339 use and control of Common Ravens. Proceedings of the Vertebrate Pest Conference 20:110-113.

Temple, S.A. 1974. Winter food habits of ravens on the Arctic Slope of Alaska. Arctic 27:41-46.

Watts, P.D., B.A. Draper, and P.D. IDLE. 1991. Environmental elements on roost selection in wintering ravens at Churchill, Manitoba, Canada. Arctic and Alpine Research 23:66-70.
Webb, W.C., W. Boarman, And J. Rotenberry. 2004. Common Raven juvenile survival in a human-augmented landscape. Condor 106:517-528.

Wright, J., R.E. Stone, AND N. Brown. 2003. Communal roosts as structured information centres in the raven, Corvus corax. Journal of Animal Ecology 72: 1003-1014.

Received 23 October 2015 Accepted 8 June 2017 Published online 19 October 2017 